\title{
Peroxide Immobilization of a Silicone Stationary Phase on a
}

\section{Support}

\author{
Rosana de Cassia de Souza Schneider ${ }^{a, b}$, Ionara Regina Pizzutti ${ }^{a}$, and Mar- \\ tha Bohrer Adaime $*^{a}$ \\ ${ }^{a}$ Departamento de Química, Universidade Federal de Santa Maria, C.P. 5051, \\ 97119-911 Santa Maria - RS, Brazil \\ ${ }^{b}$ Departamento de Química e Física, Universidade de Santa Cruz do Sul, C.P. 155, \\ 96815-010 Santa Cruz do Sul - RS, Brazil
}

Received: April 22, 1996; October 11, 1996

\begin{abstract}
A imobilização de uma fase estacionária de silicone (SE-30) sobre Chromosorb W-AW para uso em cromatografia gasosa foi iniciada por peróxido de dicumila (DCUP). Foram estudadas concentrações apropriadas de peróxido e o procedimento utilizado para imobilização é bem descrito.

Foram realizados testes de extrações com solventes, avaliação cromatográfica, bem como estabilidade térmica e lavagem com solventes em coluna. Estes testes mostraram que a preparação de SE-30 imobilizada sobre Chromosorb W-AW, usando DCUP, é simples e produz fases estacionárias eficientes e resistentes a solventes.

The immobilization of a silicone stationary phase (SE-30) on Chromosorb W/AW for use in packed column gas chromatography was initiated by dicumyl peroxide (DCUP). Appropriate peroxide concentrations were studied and the immobilization procedure is described.

Solvent extractions and chromatographic testing, as well as thermal stability and on-column solvent rinsing, showed that preparation of an SE-30 phase immobilized on Chromosorb W/AW using DCUP is a simple method that produces efficient and non-extractable stationary phases.
\end{abstract}

Keywords: gas chromatography, packed columns, organic peroxide immobilization, immobilized stationary phases

\section{Introduction}

Liquid stationary phases used in gas chromatography present limitations with respect to volatility and thermal stability which impose upper temperature limits on their use. These problems are ameliorated by the immobilization of the stationary phase through bonding between the polymer chains with possible bonding to the support. This immobilization process is initiated by free radicals which are produced by heat ${ }^{1-5}$, chemical initiators such as azocompounds $^{6-8}$, peroxides ${ }^{9-13}$ or ozone ${ }^{14,15}$, and ionizing radiation such as electrons ${ }^{16}, \gamma$ radiation $^{17,18}$, and low-temperature plasmas ${ }^{19}$. All of these methods have been successfully applied to produce immobilized nonpolar silicone phases within capillary columns. However, very little information exists about immobilization of supported stationary phases used in packed-column gas chromatography.

This project was initiated to study the peroxide immobilization of SE-30 (silicone phase) on supports. Compared with other methods, peroxide-initiated cross-linking is easier to perform, and in addition, the necessary chemicals are readily available. Appropriate peroxide concentrations were studied and the details of the immobilization procedure are described here. 


\section{Experimental}

\section{Materials}

15\% SE-30 (Merck) on Chromosorb W/AW (80-100 mesh, Merck) was prepared by evaporating chloroform. This material was suspended in chloroform containing dicumyl peroxide (DCUP, Merck) at concentrations varying from 1 to $10 \% \mathrm{w} / \mathrm{w}$. After evaporation of the solvent, known quantities of the coated solid were placed in ampoules which were sealed under air and heated to different temperatures $\left(150,210\right.$ and $250{ }^{\circ} \mathrm{C}$ ) for $10 \mathrm{~h}$.

\section{Equipment}

A Varian 3300 Gas Chromatograph with a flame ionization detector, coupled to a Varian 4400 integrator, was used with $2 \mathrm{~m} \times 2 \mathrm{~mm}$ (i. d.) silanized glass columns placed in such a way as to permit on-column injection.

Infrared spectra were taken on a Bruker model IFS 28 spectrophotometer, while visible spectra were obtained on a Micronal model B 260 spectrophotometer.

\section{Testing procedures}

Solvent extractions of treated and non-treated packing materials were carried out at reflux temperature for six hours with each of three solvents (methanol, benzene and chloroform) using a modification of the method from Sanchez et al. ${ }^{20}$.

Methylene blue adsorption on the active surface, used to determine the relative difference between well-coated and non-coated particles, was carried out by a modification of the method from Shapiro and Kolthoff ${ }^{21}$. Known quantities of the packing materials were stirred in contact with an ethanolic solution containing $10 \mu \mathrm{g} \mathrm{mL}^{-1}$ of methylene blue. After a fixed time, the suspension was filtered and the absorbance of the methylene blue remaining in solution was measured at $610 \mathrm{~nm}$. The activity of the surface was determined from the difference in absorption between pure methylene blue solution and the filtered methylene blue solution after contact.

For chromatographic testing, the prepared phases were packed into identical glass columns with the aid of a vibrator. The packing density was controlled by the weight of the packing used.
Table 1. The percentage of the liquid stationary phase (SE-30) extracted by solvents as a function of the dicumyl peroxide concentration used for immobilization*.

\begin{tabular}{|c|c|c|c|c|c|c|}
\hline \multirow{2}{*}{$\begin{array}{l}\text { DCUP } \\
(\%)\end{array}$} & \multirow{2}{*}{$\begin{array}{c}\text { Temp. } \\
\left({ }^{\circ} \mathrm{C}\right)\end{array}$} & \multicolumn{4}{|c|}{$\%$ Extracted with } & \multirow{2}{*}{$\begin{array}{c}\text { Immob. } \\
(\%)\end{array}$} \\
\hline & & $\mathrm{CH}_{3} \mathrm{OH}$ & $\mathrm{C}_{6} \mathrm{H}_{6}$ & $\mathrm{CHCl}_{3}$ & Total & \\
\hline \multirow[t]{4}{*}{0} & 25 & 1.2 & 0.0 & 14.2 & 15.4 & - \\
\hline & 150 & 0.2 & 0.2 & 14.8 & 15.2 & - \\
\hline & 210 & 0.8 & 0.4 & 12.8 & 14.0 & - \\
\hline & 250 & 0.9 & 0.3 & 14.3 & 15.5 & - \\
\hline \multirow[t]{3}{*}{1} & 25 & 1.2 & 1.7 & 11.6 & 14.5 & - \\
\hline & 150 & 0.1 & 0.0 & 13.9 & 14.0 & - \\
\hline & 250 & 0.6 & 0.1 & 11.5 & 12,2 & - \\
\hline \multirow[t]{2}{*}{2} & 25 & 2.1 & 0.2 & 13.1 & 15.4 & - \\
\hline & 250 & 0.2 & 1.3 & 13.9 & 15.4 & - \\
\hline \multirow[t]{2}{*}{5} & 25 & 2.5 & 0.2 & 13.0 & 15.7 & - \\
\hline & 250 & 0.4 & 0.1 & 7.5 & 8.0 & 47 \\
\hline \multirow[t]{3}{*}{8} & 25 & 4.6 & 0.3 & 10.7 & 15.6 & - \\
\hline & 210 & 1.0 & 1.3 & 0.5 & 2.8 & 82 \\
\hline & 250 & 0.4 & 1.0 & 1.0 & 2.4 & 84 \\
\hline \multirow[t]{3}{*}{10} & 25 & 2.7 & 2.1 & 10.9 & 15.7 & - \\
\hline & 210 & 1.0 & 3.3 & 0.2 & 4.5 & 71 \\
\hline & 250 & 0.7 & 2.2 & 0.1 & 3.0 & 81 \\
\hline
\end{tabular}

*The phases were prepared with $15 \%$ SE-30/Chromosorb W/AW w/w.

Two different mixtures (A: decane, undecane, and dodecane, and B: methyl hexanoate and methyl octanoate) were used to evaluate the chromatographic parameters of the phases at $160{ }^{\circ} \mathrm{C}(\mathrm{A})$ and $140{ }^{\circ} \mathrm{C}(\mathrm{B})$, with a flow rate of $30 \mathrm{~mL} \mathrm{~min}^{-1}\left(\mathrm{~N}_{2}\right)$. The $\mathrm{t}_{\mathrm{M}}$ was determined with butane at three different temperatures $\left(170,180\right.$, and $\left.200{ }^{\circ} \mathrm{C}\right)$.

The columns were submitted to high temperatures $\left(\sim 350{ }^{\circ} \mathrm{C}\right)$, and the background current was registered to verify the thermal stability.

The extractability of the stationary phase film was checked in the following way. The packed column was successively washed with $2.5 \mathrm{~mL}$ acetone, $1.8 \mathrm{~mL}$ methylene chloride: isooctane (1:1), $1.8 \mathrm{~mL}$ methylene chloride: isooctane (1:4), and finally, $2.5 \mathrm{~mL}$ isooctane. Each column was tested prior to rinsing and after rinsing. 


\section{Results}

Solvent extraction of the stationary phase is shown in Table 1. The infrared spectra are presented in Table 2. Table 3 compares the chromatographic parameters measured for a non-immobilized phase with a phase prepared with $8 \%$ DCUP at $250{ }^{\circ} \mathrm{C}$. The effect of immobilization on thermal stability is shown by determining the background current as presented in Fig. 1. The results of rinsing with solvents are shown in Fig. 2.

\section{Discussion}

Solvent extraction of the stationary phase removes the non-immobilized polymethylsilicone from the support, and the final and initial weight differences provide the total percent extracted and consequently the total percent immobilized. As shown in Table 1, 8 and 10\% of DCUP immobi- lize a significant quantity of the phase (up to $80 \%$ at either

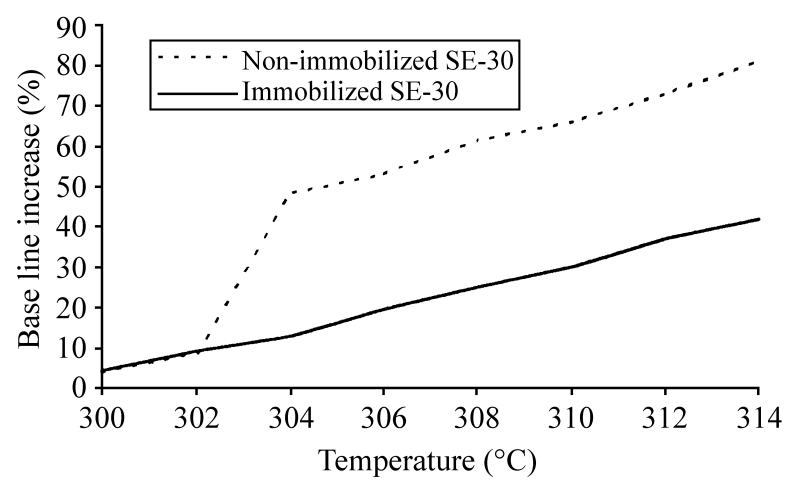

Figure 1. The effect of SE-30 immobilization on the background current.

Table 2. Infrared bands present in the immobilized supports*.

\begin{tabular}{lcccccc}
\hline DCUP & Temp. & \multicolumn{5}{c}{ Wave Number $\left(\mathrm{cm}^{-1}\right) /$ Characteristic Group } \\
\cline { 3 - 7 }$(\%)$ & $\left({ }^{\circ} \mathrm{C}\right)$ & $3500 / \mathrm{Si}-\mathrm{OH}$ & $2960 / \mathrm{CH}_{2} \mathrm{CH}_{3}$ & $1300 / \mathrm{Si}-\mathrm{O}-\mathrm{CH}_{3}$ & $1100 / \mathrm{Si}-\mathrm{O}-\mathrm{Si}$ & $800 / \mathrm{Si}-\mathrm{H}$ \\
\hline 0 & 25 & $\mathrm{x}$ & $\mathrm{x}$ & $\mathrm{x}$ & $\mathrm{x}$ & $\mathrm{x}$ \\
1 & 250 & $\mathrm{x}$ & $\mathrm{x}$ & $\mathrm{x}$ & $\mathrm{x}$ & $\mathrm{x}$ \\
5 & 250 & $\mathrm{x}$ & $\mathrm{x}$ & $\mathrm{x}$ & $\mathrm{x}$ & $\mathrm{x}$ \\
8 & 250 & - & $\mathrm{x}$ & $\mathrm{x}$ & $\mathrm{x}$ & $\mathrm{x}$ \\
10 & 250 & - & $\mathrm{x}$ & $\mathrm{x}$ & $\mathrm{x}$ & $\mathrm{x}$ \\
\hline
\end{tabular}

* The $\mathrm{x}$ indicates the presence of this band in the spectrum. The phases were prepared with $15 \%$ SE-30/ Chromosorb W/AW (w/w).

Table 3. Plate heights calculated for alkanes and methyl esters.

\begin{tabular}{|c|c|c|c|c|}
\hline Column* & Compound & $\mathrm{k}$ & $\mathrm{H}(\mathrm{mm})$ & Rs \\
\hline \multirow{8}{*}{ non-immobilized } & decane & 2.08 & 1.920 & \\
\hline & & & & 4.0 \\
\hline & undecane & 5.22 & 1.650 & \\
\hline & & & & 4.7 \\
\hline & dodecane & 9.31 & 1.290 & \\
\hline & methyl hexanoate & 4.57 & 0.909 & \\
\hline & & & & 11.7 \\
\hline & methyl octanoate & 14.08 & 0.668 & \\
\hline \multirow{8}{*}{$\begin{array}{l}\text { immobilized } \\
8 \% \text { DCUP/ } 250{ }^{\circ} \mathrm{C}\end{array}$} & decane & 2.08 & 1.660 & \\
\hline & & & & 4.7 \\
\hline & undecane & 3.93 & 0.960 & \\
\hline & & & & 5.8 \\
\hline & dodecane & 7.13 & 0.930 & \\
\hline & methyl hexanoate & 3.08 & 0.834 & \\
\hline & & & & 11.8 \\
\hline & methyl octanoate & 9.83 & 0.668 & \\
\hline
\end{tabular}

\footnotetext{
* The phases were prepared with 15\% SE-30/ Chromosorb W/AW (w/w).
} 


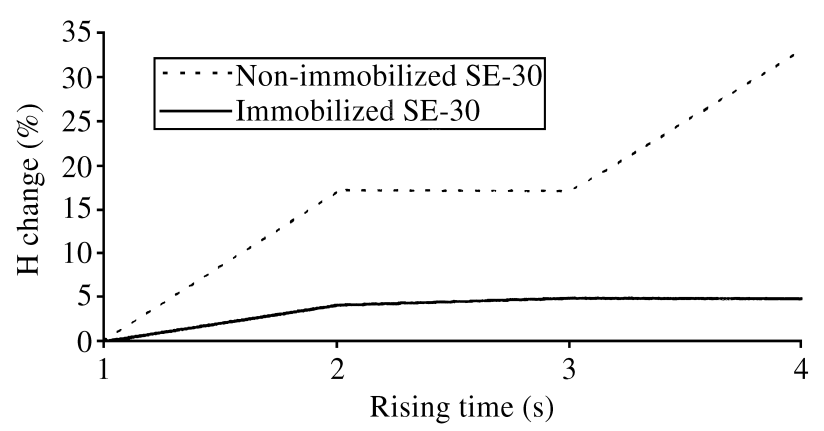

Figure 2. Plate height change for decane in different rinsing times: $1=$ before rinsing; $2=$ After $2.5 \mathrm{~mL}$ Acetone and $1.8 \mathrm{~mL}$ acetone:methylene chloride (1:1) injections; 3 = After $2.5 \mathrm{~mL}$ methylene chloride and $1.8 \mathrm{~mL}$ methylene chloride:isooctane (1:1) injections; $4=$ after rinsing.

210 or $250^{\circ} \mathrm{C}$ ). Lower percentages of DCUP do not result in significant levels of immobilization.

The infrared spectra (Table 2) show that the free silanol band $\left(3500 \mathrm{~cm}^{-1}\right)$ is absent in the phases prepared with 8 and $10 \%$ of DCUP, indicating the removal or screening of surface silanols. This is important because the surface silanols, when not coated, can react with the sample during chromatographic separation and produce assymetric peaks.

The immobilized column has a smaller plate height and higher resolution than the non-immobilized column, while the retention factor $(\mathrm{k})$ decreased for the majority of compounds after immobilization (Table 3). Thus, separations on the immobilized column are faster and more efficient.

These results are similar to those obtained by Ghaoui $e t$ $a l .{ }^{22}$ with SE-54 on Chromosorb W/AW, which was 75 to $98 \%$ immobilized using $0.30 \%$ DCUP at $180{ }^{\circ} \mathrm{C}$ for $3 \mathrm{~h}$. The lower peroxide concentration used by these authors is probably due to the presence of a vinyl substituent in SE-54 that facilitates the immobilization process.

The temperature needed to bring about a $40 \%$ increase in the background current is $156^{\circ} \mathrm{C}$ higher for immobilized SE-30 than for the non-immobilized phase, indicating a significant increase in stability with temperature programming (Fig 1).

After the rinsing sequence, the columns were evaluated. The plate heights of the columns were determined.

After successive rinsing steps the immobilized SE-30 showed a smaller plate height variation than did non-immobilized SE-30 (Fig 2).

\section{Conclusion}

The preparation of an SE-30 phase immobilized on Chromosorb W/AW using DCUP is a simple method that produces efficient and non-extractable columns, indicating a longer useful life and the possibility of the recuperation of a contaminated column.

\section{Acknowledgments}

The authors express their appreciation to $\mathrm{CNPq}$, FAPERGS, FIPE-UFSM and UNISC for financial support for several aspects of this project, and to Carol Collins for helpful conversations . RCSS also wishes to thank CNPq for a fellowship.

\section{References}

1. Aue, W.A.; Hastings, C.R.; Kapila, S. J. Chromatogr. 1973, 77, 299.

2. Lipsky, S.R.; McMurray, W.J. J. Chromatogr. 1982, 239, 61.3.

Petsev, N.D.; Pekov, G.I.; Alexandrova, M.D.; Dimitrov, C. Chromatographia 1985, 20, 228.

4. Sandra, P.; David, F.; McNair, H.M. Analysis 1992, 20, 117.

5. Lai, G.; Mühleck, U.; Nicholson, G.J.; Schmid, J.; Bayer, E. Chromatographia 1991, 32, 241.

6. Richter, B.E.; Kuei, J.C.; Park, N.J.; Crowley, S.J.; Bradshaw, J.S.; Lee, M.L. J. High Resolut. Chromatogr. Chromatogr. Commun. 1983, 6, 371.

7. Janák, K.; Horká, M.; Tesarík, K. J. Chromatogr. 1989, 471, 237.

8. M. Horká, V. Kahle and M. Krejcí, J. Chromatogr. 1993, 637, 96.

9. K. Grob and G. Grob, J. Chromatogr. 1981, 211, 243.

10. B.W. Wright, P.A. Peaden and M.L. Lee, J. Seark, J. Chromatogr. 1982, 248, 17.

11. L. Blomberg, J. Buijten, K. Markides and T. Wannman J. Chromatogr. 1982, 239, 51.

12. R.T. Ghijsen, F. Nooitgedacht, H. Poppe Chromatographia 1986, 22, 201.

13. M. Cigánek, M. Dressler and J. Teply J. Chromatogr. 1991, 588, 225.

14. K. Grob, and G. Grob J. Chromatogr. 1981, 213, 211.

15.C.H. Chuang, H. Shanfield, A. Zlatkis Chromatographia 1987, 3, 169.

16. K. Markides, L. Blomberg, J. Buijten and T. Wämman J. Chromatogr. 1983, 267, 29.

17. J.A. Hubball and P.R. DiMauro, F. Barry, E.A. Lyons, and W.A. George J. Chromatogr. Sci. 1984, 22, 185.

18. M.A. Basso, M.J.T.F. dos Santos, K.E. Collins and C.H. Collins J. High Resolut. Chromatogr. Chromatogr. Commun. 1989, 7, 500.

19. S.R. Springston and D.A. Dezaro J. Chromatogr. 1989, 473, 79.

20. E.F. Sanchez, J.A.G. Dominguez, J.G. Muñoz and M.J. Molera J. Chromatogr. 1984, 299, 151.

21. J. Shapiro and I.M. Kolthoff J. Am. Chem. Soc. 1950, 72,776

22. L. Ghaoui, H. Shanfield, A. Zlatkis Chromatographia 1984, 18, 11. 